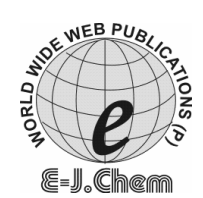

http://www.e-journals.net
ISSN: 0973-4945; CODEN ECJHAO

E-Journal of Chemistry 2008, 5(S2), 1081-1086

\title{
A Simple and Rapid RP-HPLC Method for the Estimation of Nevirapine in Bulk and Pharmaceutical Dosage Forms
}

\author{
PALANIAPPAN MOHANRAJ, DEB KUMAR SARKAR, \\ TIRTHANKAR CHOUDHURY and KARUNAKARAN GAUTHAMAN* \\ Department of Pharmaceutical Sciences, \\ Himalayan Pharmacy Institute, \\ E.Sikkim-737136, India. \\ gauthamank@gmail.com; Fax: +91-3592-246462
}

Received 9 March 2008; Accepted 22 April 2008

\begin{abstract}
A reverse phase HPLC method is described for the determination of nevirapine in tablet dosage forms. Chromatography was carried on an ODS column using a mixture of methanol and water $(89: 11 \mathrm{v} / \mathrm{v})$ as the mobile phase at a flow rate of $1 \mathrm{~mL} / \mathrm{min}$ with detection at $284 \mathrm{~nm}$. The retention time of the drug was $3.22 \mathrm{~min}$. The detector response was linear in the concentration of $25-200 \mathrm{mcg} / \mathrm{mL}$. The limit of detection and limit of quantification was 0.004 and $0.0121 \mathrm{mcg} / \mathrm{mL}$ respectively. The percentage assay of nevirapine was $99.52 \%$. The method was validated by determining its sensitivity, accuracy and precision. The proposed method is simple, economical, fast, accurate and precise and hence can be applied for routine quality control of nevirapine in bulk and tablet dosage forms.
\end{abstract}

Keywords: Nevirapine, RP-HPLC, Estimation, Tablet dosage forms.

\section{Introduction}

Nevirapine, 11-cyclopropyl-5,11-dihydro-4-methyl-6H-dipyrido[3,2-b:2',3'-e][1,4] diazepin 6-one ${ }^{1}$ is a non-nucleoside reverse transcriptase inhibitor (NNRTI) of human immunodeficiency virus type 1 (HIV-1). Treatment with nevirapine mono-therapy is notorious for rapidly eliciting resistance due to mutations of the amino acids surrounding the NNRTI binding site ${ }^{2}$. However, in association with two other antiretroviral products, nucleoside reverse transcriptase inhibitors (NRTIs) and/or protease inhibitors (PIs), nevirapine significantly reduces the viral load and increases CD4 cell count, particularly in treatment-naive patients ${ }^{3}$. 
Nevirapine is metabolized by cytochrome P450 (CYP3A4) and is a relatively potent inductor of the enzyme; consequently, it has the ability to reduce plasma concentrations of other drugs that are also biotransformed by CYP3A4 as PIs ${ }^{4}$. Therapeutic drug monitoring of nevirapine may be warranted to prevent or delay the occurrence of viral resistance, and to ensure optimal therapy for HIV-infected patients. ${ }^{5}$. Literature survey reveals that chromatographic methods for the determination of nevirapine in tablet dosage forms by simultaneous quantification with other drugs HPTLC ${ }^{6}$, several HPLC ${ }^{7-13}$ methods in combination with other antiretrovirals by plasma levels. Marzolini $\mathrm{C}^{14}$ et al. describe method in transplacental passage at delivery in pregnant woman, but due to ethical concern, pregnant women are generally excluded from clinical trials ${ }^{15}$ and $\mathrm{LC} / \mathrm{MS} / \mathrm{MS}^{16}$ method in human plasma with other antiretroviral drugs, Few individual HPLC methods developed for nevirapine like Hollanders $\mathrm{R} \mathrm{M} \mathrm{F}^{17}$ et al. developed a method in phosphate buffer and acetonitrile with flow rate $1.5 \mathrm{~mL} / \mathrm{min}$ and retention time was $6.5 \mathrm{~min}$, Joesph $\mathrm{W} \mathrm{P}^{18}$ et al. developed method LC-8 analytical column with mobile phase phosphate buffer,1-butane sulfonic acid as anion pair reagent, methanol and acetonitrile and peak area was detected with retention time $10 \mathrm{~min}$ at a flow rate of $1.0 \mathrm{~mL} / \mathrm{min}$. Lopaz $\mathrm{R}$ $\mathrm{M}^{19}$ et al. showed chromatogram with phosphate buffer and acetonitrile as mobile phase at a flow rate of $1 \mathrm{~mL} / \mathrm{min}$ with retention time was $2 \mathrm{~min}$. Our aim is to report an isocratic RP-HPLC method for the estimation of nevirapine with mobile phase methanol and water used as mobile phase in the ratio of $(89: 11)$, and flow rate $1 \mathrm{~mL} / \mathrm{min}$, retention time was $3.22 \mathrm{~min}$. This paper reports simple, economical, accurate, reliable and reproducible analytical method for the estimation of nevirapine in formulation. This procedure is applied successfully for the analysis of the commercial tablets, purchased from market and the results are compared statistically.

\section{Experimental}

Nevirapine was obtained as a gift sample from Cipla Ltd, Methanol HPLC grade (S.d. fineChem Ltd.), Water HPLC grade (Universal Laboratories Pvt. Ltd.), were used.

\section{Instrument}

RP-HPLC was performed in Shimadzu (Japan) HPLC VP Series, Pump LC 20AT \& UV Detector model SPD-20A with Rheodyne injector and $20 \mu \mathrm{L}$ loop. The column used was C18-ODS-Hypersil column $(250 \mathrm{~mm} \times 4.6 \mathrm{~mm}, 5 \mu)$. Spinchrome (Mumbai, India) computer based data station was used.

\section{Chromatographic conditions}

Chromatographic separations were achieved using a Luna 5u C18 Hypersil column $(250 \times 4.6 \mathrm{~mm}, 5 \mu)$. The mobile phase consisting of methanol and water $(89: 11 \mathrm{v} / \mathrm{v})$ was passed through $0.45 \mu \mathrm{m}$ membrane filter and degassed by ultrasonication. The flow rate was maintained at $1 \mathrm{~mL} / \mathrm{min}$ and the measurements were made at $284 \mathrm{~nm}$. The column and the RP-HPLC system were kept in ambient temperature.

\section{Preparation of standard stock solution}

Accurately weighed $100 \mathrm{mg}$ of nevirapine standard was taken in $100 \mathrm{~mL}$ volumetric flask. This was dissolved in $70 \mathrm{~mL}$ of methanol and sonicated for $30 \mathrm{~min}$ and then diluted to $30 \mathrm{~mL}$ with the mobile phase to get $1 \mathrm{mg} / \mathrm{mL}$ standard stock solution.

\section{Preparation of sample solution}

Each twenty tablets (Nevimune, Nevivir, Cipla Ltd.) were weighed accurately and finely powdered. The powder equivalent to $100 \mathrm{mg}$ was taken in $100 \mathrm{~mL}$ volumetric flask. 
This was dissolved in $70 \mathrm{~mL}$ methanol and sonicated for $30 \mathrm{~min}$ with internal shaking. Then the volume was finally made to $100 \mathrm{~mL}$ with mobile phase to get a clear solution of $1 \mathrm{mg} / \mathrm{mL}$. The above solution was centrifuged at $3000 \mathrm{rpm}$ for $5 \mathrm{~min}$.

\section{Linearity}

Several aliquots of standard stock solutions $0.25,0.5,0.75,1.0,1.25,1.5,1.75$ and $2.0 \mathrm{~mL}$ of nevirapine were taken in different $10 \mathrm{~mL}$ volumetric flask and diluted up to the mark with methanol. Evaluation was performed with Ultra-Violet Dual alpha absorbance detector at $284 \mathrm{~nm}$. Peak area was recorded for all the peaks and a calibration graph was obtained by plotting peak area versus concentration of nevirapine (Figure 1). The plot of peak area of each sample against respective concentration of nevirapine was found to be linear in the range of $25.0-200.0 \mu \mathrm{g} / \mathrm{mL}$, using regression analysis the linear equation $\mathrm{Y}=15.71 \mathrm{x}-2.116$ with correlation coefficient of $r^{2}=0.9999$. Linear regression least square fit data obtained from the measurements are given in Table 1.

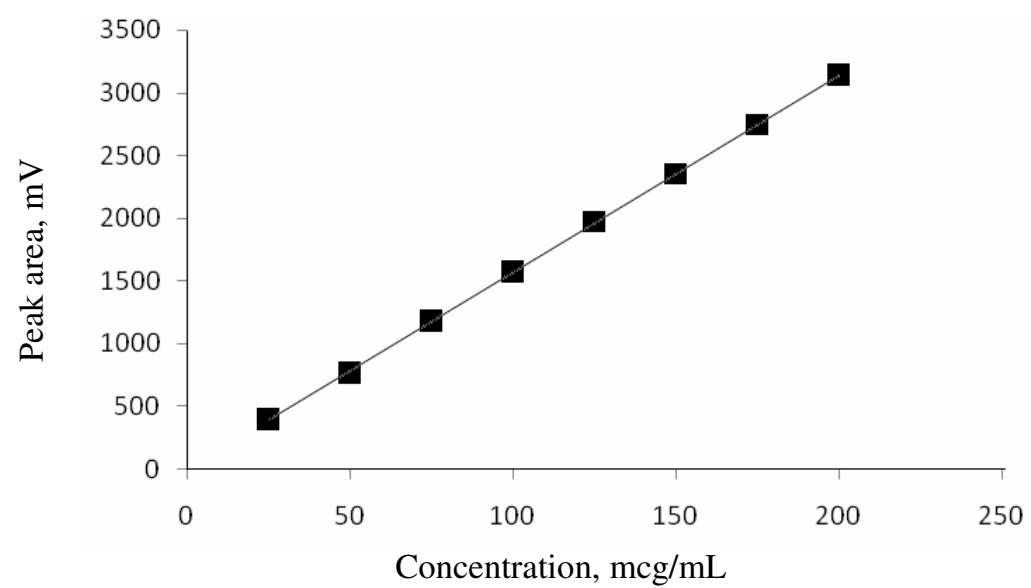

Figure 1. Calibration curve of nevirapine by RP- HPLC

Table 1. Calibration curve points of the proposed method

\begin{tabular}{cc}
\hline $\begin{array}{c}\text { Concentration of nevirapine } \\
\mu \mathrm{g} / \mathrm{mL}\end{array}$ & $\begin{array}{c}\text { Peak area* } \\
\mathrm{mV} . \mathrm{s}\end{array}$ \\
\hline 25 & 396.208 \\
50 & 770.874 \\
75 & 1179.528 \\
100 & 1574.426 \\
125 & 1969.221 \\
150 & 2351.261 \\
175 & 2745.28 \\
200 & 3142.885 \\
\hline
\end{tabular}

*Mean of five determinations.

\section{Results and Discussion}

The system suitability tests were carried out on freshly prepared standard stock solution of nevirapine. Parameters that were studied to evaluate the suitability of the system are given in Table 2. 
Table 2. System suitability test parameters

\begin{tabular}{lc}
\hline Parameters & Values \\
\hline HETP, $\mathrm{mm}$ & 0.009 \\
Tailing factor & 1.113 \\
Theoretical plates $/ \mathrm{m}$ & 110099.73 \\
Resolution & 2.38 \\
LOD,$\mu \mathrm{g} / \mathrm{mL}$ & 0.004 \\
LOQ, $\mu \mathrm{g} / \mathrm{mL}$ & 0.0121 \\
\hline
\end{tabular}

\section{Limit of detection (LOD) and limit of quantification (LOQ)}

The limit of detection (LOD) and limit of quantification (LOQ) for nevirapine were found to be 0.004 and $0.0121 \mu \mathrm{g} / \mathrm{mL}$ respectively. The signal to noise ratio is 3 for LOD and 10 for LOQ. From the typical chromatogram of nevirapine as shown in Figure 2, it was found that the retention time was $3.22 \mathrm{~min}$. A mixture of methanol and water ratio of 89:11 v/v was found to be most suitable to obtain a peak well defined and free from tailing. In the present developed HPLC method, the standard and sample preparation required less time and no tedious extraction were involved. A good linear relationship $\left(\mathrm{r}^{2}=0.9999\right)$ was observed between the concentration range of $25.0-200.0 \mathrm{mcg} / \mathrm{mL}$. The precision of the method was determined by repeatability (intra-day) and intermediate precision (inter-day) and was expressed as CV (\%) of a series of measurement Table 3. The result obtained shows CV (\%) less than $1 \%$ indicating good intra-day precision.

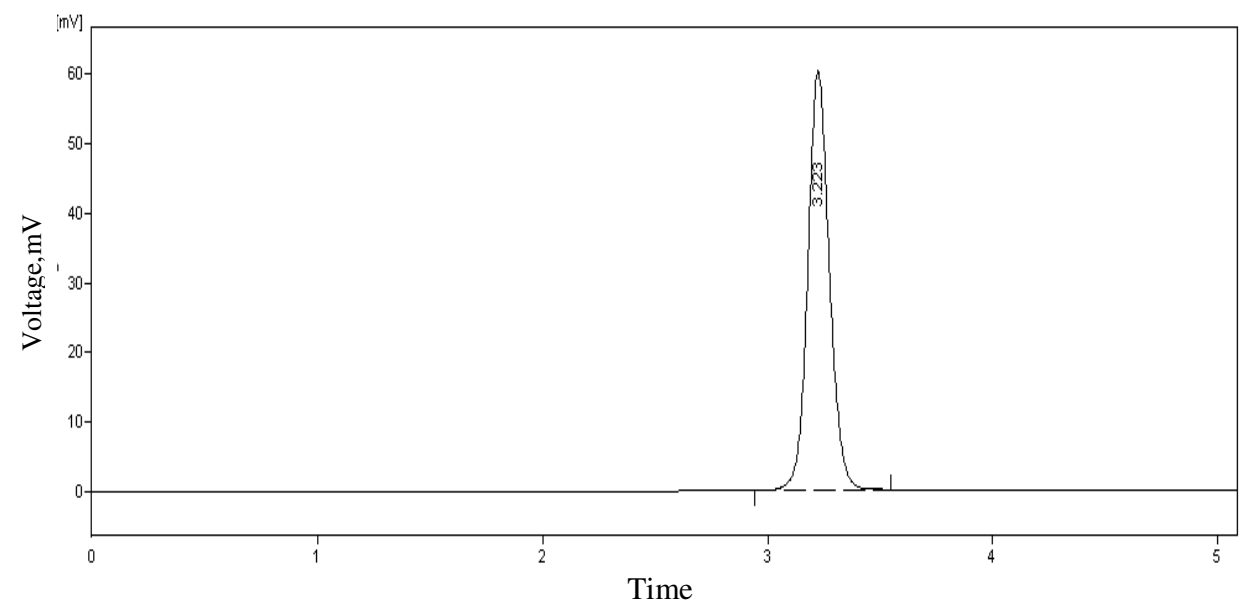

Figure 2. A typical chromatogram of nevirapine by RP- HPLC

Table 3. Intra and inter - day precision for nevirapine assay

\begin{tabular}{ccccr}
\hline $\begin{array}{c}\text { Conc. of nevirapine } \\
\mu \mathrm{g} / \mathrm{mL}\end{array}$ & \multicolumn{4}{c}{ Concentration of nevirapine found } \\
\cline { 2 - 5 } & Intra-day & \multicolumn{3}{c}{ Inter-day } \\
\cline { 2 - 5 } & Mean, $\mathrm{n}=5$ & $\mathrm{CV}, \%$ & Mean, $\mathrm{n}=5$ & $\mathrm{CV}, \%$ \\
\hline 50 & 50.05 & 0.61 & 50.51 & 0.99 \\
100 & 99.63 & 1.21 & 99.47 & 0.28 \\
200 & 200.14 & 0.93 & 200.16 & 1.03 \\
\hline
\end{tabular}


The assay of nevirapine tablets was found to be $99.52 \%$. The results are given in Table 4. From the recovery studies it was found that about $99.56 \%$ of nevirapine was recovered which indicates high accuracy of the method. The results are given in Table 5. The absence of additional peaks in the chromatogram indicates non interference of the common excipients used in the tablets. This demonstrates that the developed HPLC method is simple, linear, accurate, sensitive and reproducible. Thus, the developed method can be easily used for the routine quality control of bulk and tablet dosage form of nevirapine within a short analysis time.

Table 4. Results of assay of formulation by the proposed method

\begin{tabular}{lccc}
\hline Sample & $\begin{array}{c}\text { Amount claim } \\
\mathrm{mg} / \mathrm{tab}\end{array}$ & $\begin{array}{c}\text { Amount found } \\
\mathrm{mg} / \mathrm{tab}\end{array}$ & \% Recovery \\
\hline 1 & 200 & 199.44 & 99.72 \\
2 & 200 & 199.79 & 99.33 \\
\hline
\end{tabular}

* Mean of five determinations.

Table 5. The recovery studies for nevirapine by proposed method

\begin{tabular}{cccc}
\hline $\begin{array}{l}\text { Labeled Claim } \\
(200 \mathrm{mg})\end{array}$ & $\begin{array}{c}\text { Amount of } \\
\text { drug added, mg }\end{array}$ & $\begin{array}{c}\text { Mean amount } \\
\text { found, mg }\end{array}$ & Mean \% Recovery* \\
\hline 1 & 10 & 10.24 & 100.39 \\
2 & 20 & 19.07 & 98.96 \\
3 & 30 & 29.88 & 99.33 \\
\hline
\end{tabular}

*Mean of five determinations.

Assay

$20 \mu \mathrm{L}$ of sample solution was injected into the injector of liquid chromatograph. The retention time was found to be $3.22 \mathrm{~min}$. The amount of drug present per tablet was calculated by comparing the peak area of the sample solution with that of the standard solution. The data are presented in Table 4.

\section{Recovery studies}

Accuracy was determined by recovery studies of nevirapine, known amount of standard was added to the preanalysed sample and subjected to the proposed HPLC analysis. Results of recovery study are shown in Table 5. The study was done at three different concentration levels.

\section{Conclusion}

Developed high performance liquid chromatographic method is simple, reliable, reproducible and economical for the analysis of nevirapine in pharmaceutical formulations. The reported method can be used successfully for the effective qualitative and quantitative analysis of nevirapine in Tablet or other pharmaceutical formulations.

\section{Acknowledgement}

The authors are very grateful to, Dr. H. P.Chhetri, The Director, Himalayan Pharmacy Institute, E. Sikkim for providing facility to perform this work.

\section{Reference}

1. The Merck Index, $14^{\text {th }}$ Ed., Merck Research Laboratories, (Monograph No:6490), 2006, p 1123.

2. De Clercq E, Il Farmaco, 1999, 54, 26-45. 
3. Barry M, Mulcahy F, Merry C, Gibbons S and Back D, Clin Pharmacokinet.,1999, 36, 289.

4. $\quad$ Malaty L I and Kupper J J, Drug Saf. 1999, 20, 147.

5. Jajaray A, Alexander J, Price C, Daly D, Pav J, Hatoxx S and Keirns J, Pharm. Res. 1995, 9, S334.

6. Anbazhagan S, Indumathy N, Shanmugapandiyan P and Sridhar S K, J. Pharm Biomed, Anal., 2005, 39, 801.

7. D' Avolio A, Siccardi M, Sciandra M, Lorena B, Bonora S, Trentini L and Perri G D, J.Chromatogr.B, 2007, 859, 234.

8. Ramachandran G, Hemanthkumar A K, Kumaraswami V and Swaminathan S, J.Chromatogr.B, 2006, 843, 339.

9. Fan B and Stewart J T, J. Pharm. Biomed. Anal., 2002, 28, 903.

10. Dailly E, Raffi F and Jolliet P, J. Chromatogr. B, 2004, 813, 335.

11. Rezk N L, Richard R, Tidwell and Kashuba A D M, J.Chromatogr.B, 2002, 774, 79.

12. Rezk N L, Richard R, Tidwell and Kashuba A D M, J.Chromatogr.B ,2004, 805, 241.

13. Aymard G, Legrand M, Trichereau N and DiquetB, J.Chromatogr.B, 2000, 774, 227.

14. Marzolini C, Beguin A, Telenti A, Schreyer A, Buclin T, Biollaz J and Decostered L A, J.Chromatogr.B , 2002, 774, 127.

15. Little B B, Bawdon R E, Christmas J T, Sobhi S, Gilstrap L and Gynecol A J O, J.Chromatogr. B, 1989, 732, 161.

16. Mistri H N, Jangid A G, Pudage A, Gomes N, Sanyal M and Shrivastav P, J.Chromatogr.B, 2007, 853, 320.

17. Hollanders R M F, Kolmer E B, Burger D M, Wuis E W, Koopmans P P and Hekster Y A, J.Chromatogr.B, 2000, 744, 65.

18. Pav J W, Rowland L S and Korpalski D J, J. Pharm Biomed. Anal., 1999, 20, 91.

19. Lopez R M, Pou L, Gomez M R, Ruiz I and Monterde J, J. Chromatogr. B, 2001, 751, 371 . 


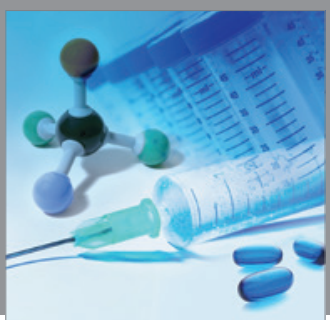

International Journal of

Medicinal Chemistry

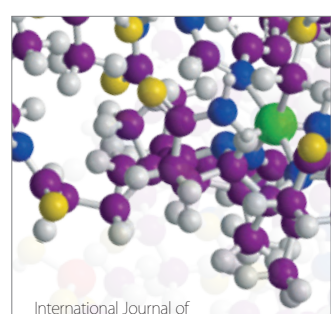

Carbohydrate Chemistry

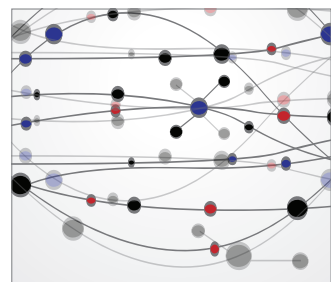

The Scientific World Journal
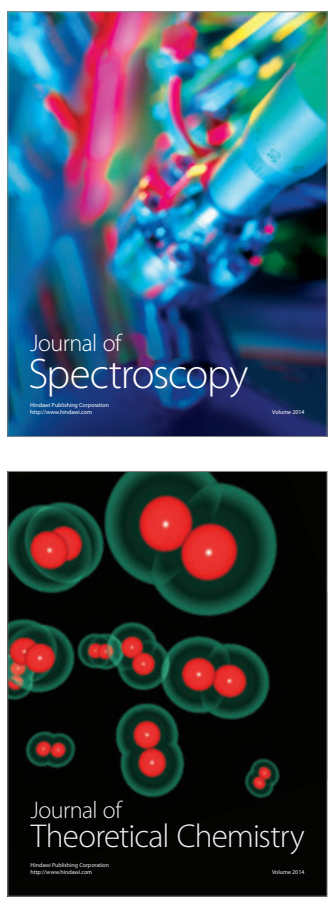
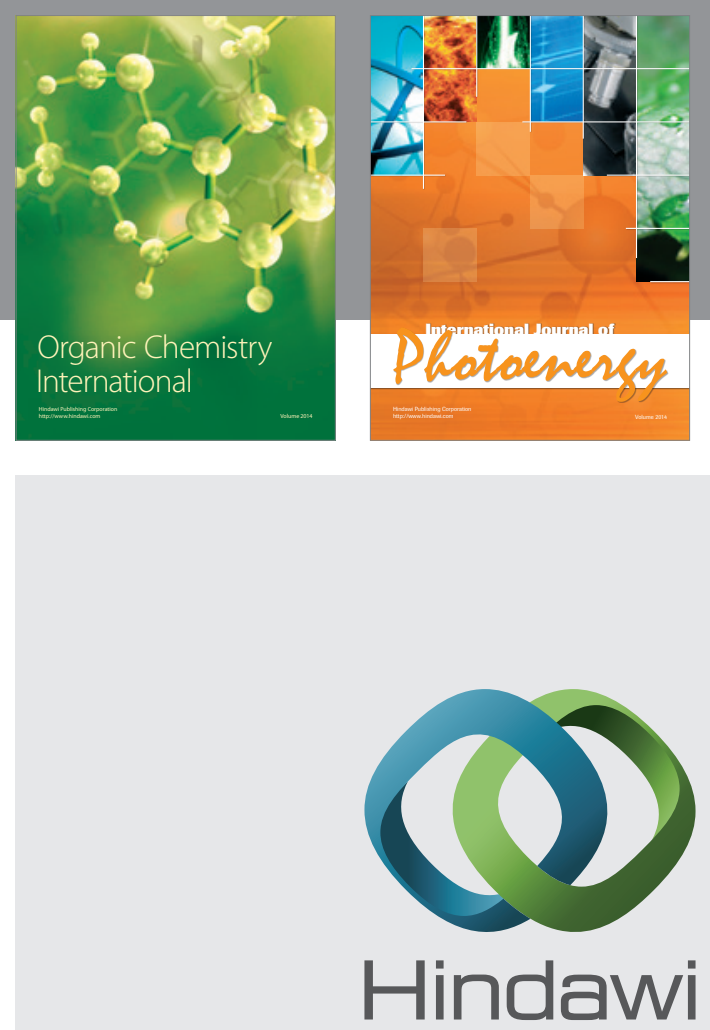

Submit your manuscripts at

http://www.hindawi.com
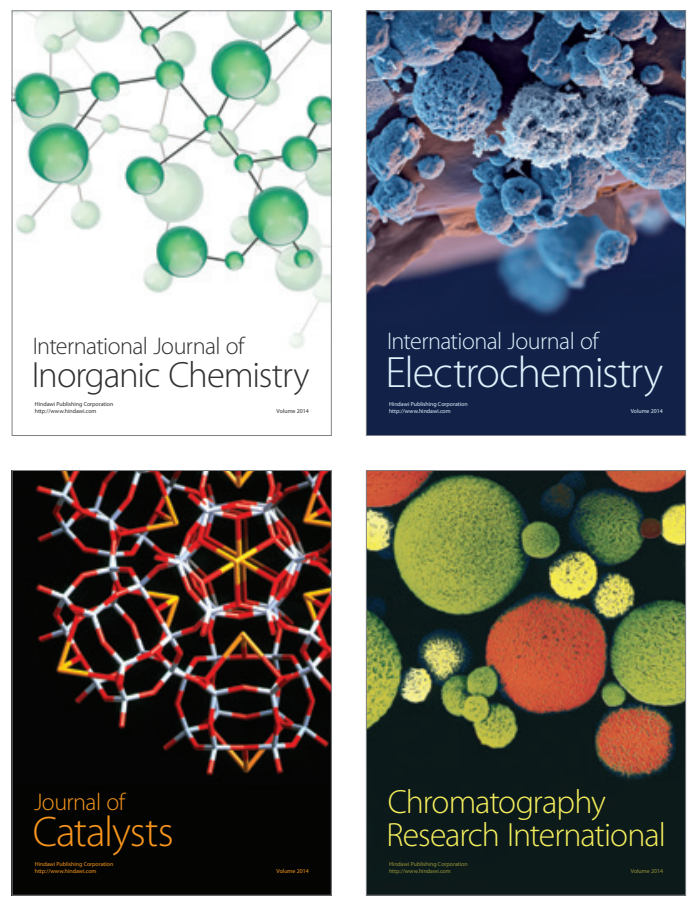
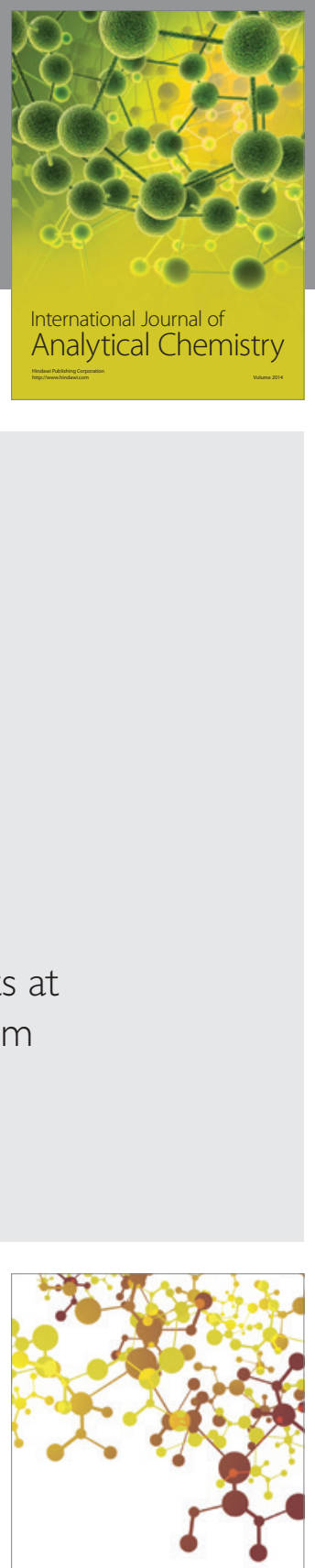

Journal of

Applied Chemistry
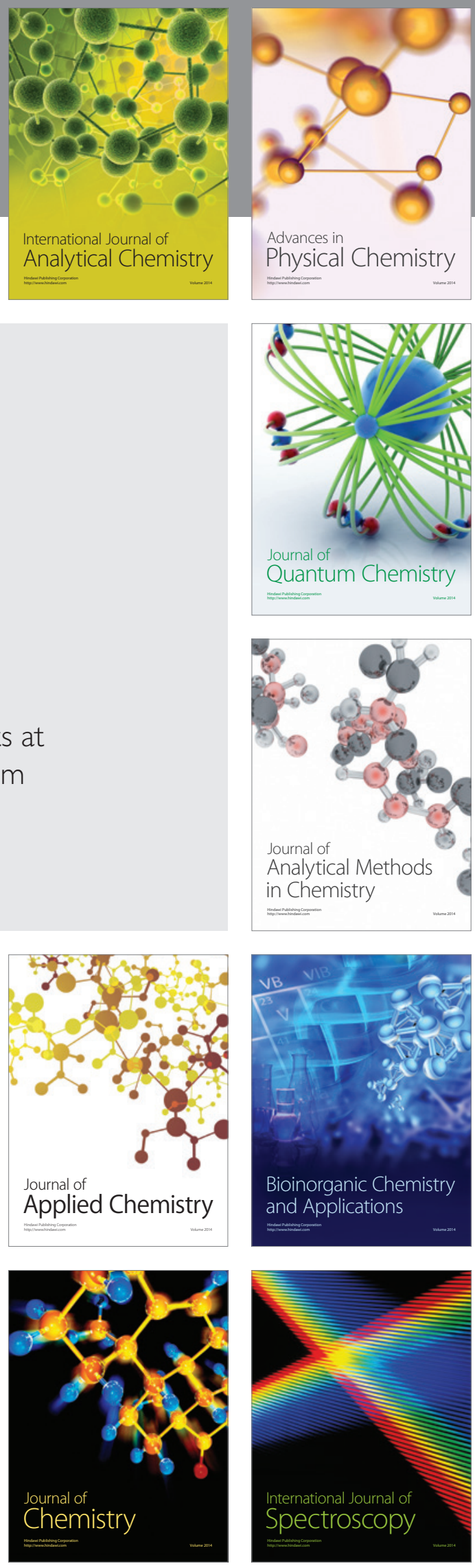